\title{
METHODS FOR ESTIMATION OF THE RIVERFLOW POTENTIAL FOR HYDROKINETIC POWER GENERATION
}

\author{
A. Kalnacs ${ }^{1}$, J. Kalnacs ${ }^{2}$, A. Mutule ${ }^{2}$, U. Persis ${ }^{3}$ \\ ${ }^{1}$ LLC "Environment, Bioenergetics and \\ Biotechnology Competence centre", \\ 21 Aizkraukles Str., LV-1006, Riga, LATVIA \\ ${ }^{2}$ Institute of Physical Energetics, \\ 21 Aizkraukles Str., LV-1006, Riga, LATVIA \\ ${ }^{3}$ LLC „BRZA Agro”, Research Institute of Agriculture, \\ Skriveri District, LV-5125 LATVIA
}

\begin{abstract}
The authors propose methods for estimation of the potential of riverflows for electricity production at hydrokinetic power plants. The methods can be applied to any river or its span where it is possible to move using a floating means. The methodical part includes validation of the flow velocity and bed depth measurement data using the available statistics as well as a case study. Analysis of the in-river measurement results for the selected spans of river Daugava shows that the flow rate variations exert only a minor influence on the flow velocity at particular sites. This testifies the hydrokinetic power plants as stable and predictable sources of electrical energy, both in a long term and, especially, in a short one. The proposed estimation methods could be useful in explorations of rivers, making them simpler and cheaper.
\end{abstract}

Keywords: Hydropower generation, hydrokinetic power plant, flow velocity, flow rate.

\section{INTRODUCTION}

The possibility to use kinetic energy of river flows for electricity generation in Latvia has so far been ignored. Development of hydrokinetic technologies [1-3] allows utilization of this potential in full measure so that it is possible to introduce into practice hydrokinetic power plants in Latvia based on the experimentally verified technologies of the type.

So far, the development of such technologies in Latvia has been impeded by the absence of data on the electricity generation via hydrokinetics (i.e. using free water flows) as well as of the methods and legal requirements for the implementation and operation of hydrokinetic power plants (HKPPs).

In our previous work [4] we estimated the potential of a river or its span (with lower Daugava taken for the research) for electricity production using hydrokinetic turbines. In the present work, we propose a detailed methodical approach to the estimation of this potential based on the previous experience. The 
developed methods can be used for exploration of any river where it is possible to sail using a boat or a similar floating means that can be kept immovable against the riverbanks.

Also under discussion in this work is the relationship between the flow rates and flow velocities, and it is shown that the influence of the former parameter on the latter is only minor.

\section{METHODS DEVELOPED FOR THE ESTIMATION}

Methodically, the estimation consists of the following consecutive steps:

1. Measurements of the flow velocity and depth of the river in its several crosssections.

2. Validation of the measurement data.

3. Exclusion from further estimation \& analysis of the river segments where the bed depth, the flow velocity or any other basic characteristic obtained are not satisfactory.

4. Rearrangement of the explored spans of the river into segments based on the basic characteristics (e.g. bed depth and flow velocity). Segments of spans left for further analysis should have similar basic characteristics throughout each of them. Some of the parameters might characterize the needs for a particular technology, e.g. the average bed depth and/or cross-section width in addition to the flow velocity. Thus, the segments will be determined where a definite number of hydrokinetic devices (HKDs) can be set up in a single cross-section (next to and/or above/below each other).

5. Calculation of the electricity production potential for all segments (see step 4). For this, the following parameters are to be defined:

a) the river cross-sectional area used for active parts of HKDs;

b) efficiency of the HKD;

c) efficiency of the electricity generator;

d) distance between HKDs in the direction of river flow;

e) the number of idle standing days of the HKPP in a year.

\section{Methods for in-river measurements}

To provide high quality of measurements and define proper places for HKPP siting in the selected river spans the recommendations given in manuals on the measurement equipment (see e.g. [5]), have to be followed. The distances between the chosen points are determined based on the experience acquired when exploring the river Daugava. Increasing these distances above a definite maximum can lead to a significant spread in the characteristics at different measurement points. In a faster river flow this maximum might be even smaller.

The sequence of actions for taking measurements is as follows.

1. The measurements of flow velocities should be taken while travelling twice by different pathways along the river spans to be explored. This should be done to evaluate the repeatability of results and define the places for the cross-sections to be measured. The distances between the measuring points might be up to $500 \mathrm{~m}$. In 
each of them the flow velocity is measured at different equally spaced depths. The spaces should be from 0.3 to $0.7 \mathrm{~m}$ (at shorter spaces the measurements will give excessive data, whereas at longer ones the accuracy will be much lower).

2. Exclusion of the segments with too low flow velocities and too shallow waters where it would be difficult (even when several cross-sections are measured) to find proper places for application of the relevant technologies. In these cases more promising river segments are to be found (see step 1).

3. Measurements of flow velocities in the river cross-sections. The distances between them can be longer in the segments where the maximum flow velocity measured in the first step is below the minimum required for stabile operation of the technology. These distances should be $\leq 1 / 3$ of the total length of the segment under exploration, not exceeding $2 \mathrm{~km}$. The distances should be shorter in the river segments where the maximum flow velocity measured in the first step was above the required minimum. In this case the distance between the measured crosssections should be $\leq 1 / 5$ of the segment total length, not exceeding $1 \mathrm{~km}$.

4. In particular cross-sections the measuring points should be spaced $1 / 6$ of the river width (thus there will be at least five such points) and $\leq 40 \mathrm{~m}$ from each other in wider rivers. The distances between the measuring points (located on the line perpendicular to the river flow) should be approx. equal. At each point the measurements are taken for the flow velocity (in several depths, see step 1) and for the depth of river bed. The GPS coordinates of the point and its height above sea level are also very important for the thorough analysis and repeatability of measurement results.

5. This last step is meant for analyzing the variations in the flow velocity depending on the flow rate, and should be taken in the cases when statistical data on the flow rate in the segments under exploration evidence that there are significant variations in this parameter. In these cases the measurements should be repeated several-fold in the same places at different flow rates (e.g. during a dry period and right after a heavy rain).

\section{Validation of the in-river measurement results}

For the validation, the relevant statistical data should be available. In Latvia, such data are collected by the State-financed observation station network [6].

The validation should be done using the statistical data for the segments where the in-river measurements were taken. If the span of a river under exploration is not covered by the mentioned network, it might be possible to obtain these data by combining those from nearby stations and obtained by measurements (see Ch. 3 for the case study).

The data on flow rates for the time of measurements are to be compared with statistical averages. If the deviations of this parameter from the statistical average are too large in some segments of the river, the corresponding measurements are not valid for the estimation. They should be repeated, otherwise satisfactory enough explanation should be provided for the deviations in order to be certain that the repeated measurements give similar results. 


\section{CASE STUDY FOR THE DEVELOPED METHODS}

In compliance with the methodical steps described above, the measurement results reported in [4] are considered in the framework of a case study. The corresponding items will thus be as follows.

1. The results of in-river measurements in the explored spans of the river Daugava are summarized in tables.

2. In the case study the following data of Latvian Environment, Geology and Meteorology Centre [6] on the average flow parameters were used:

- The flow rates in the river Daugava immediately after the Aiviekste estuary, $\mathrm{m}^{3} / \mathrm{s}$. This allowed us to determine the average flow rate in the "FIRST part" [4] for particular months in a six-year period (Table $1,1^{\text {st }}$ span column).

Table 1

Statistical \& calculated data on the flow rates in the explored spans of the river Daugava $\left(\mathrm{m}^{3} / \mathrm{s}\right)$.

\begin{tabular}{|l|c|c|c|c|c|c|c|c|c|}
\hline & \multicolumn{7}{|c|}{ Year } & $\begin{array}{c}1^{\text {st }} \text { span } \\
\text { (after } \\
\text { Aiviekste } \\
\text { estuary) }\end{array}$ & $\begin{array}{c}2^{\text {nd }} \text { span } \\
\text { (before } \\
\text { Aiviekste } \\
\text { estuary) }\end{array}$ \\
\cline { 2 - 10 } & 2006 & 2007 & 2008 & 2009 & 2010 & 2011 & 2012 & & \\
\hline January & 215 & $\mathrm{n} / \mathrm{d}$ & 315 & 303 & 546 & 548 & 483 & 401.67 & 351.46 \\
\hline February & 153 & $\mathrm{n} / \mathrm{d}$ & 481 & 409 & 298 & 609 & 275 & 370.83 & 324.48 \\
\hline March & 154 & 1335 & 1384 & 539 & 822 & 482 & & 786.00 & 687.75 \\
\hline April & 1357 & 796 & 1670 & 1964 & 3200 & 2560 & & 1924.50 & 1683.94 \\
\hline May & 564 & 730 & 727 & 620 & 1244 & 1206 & & 848.50 & 742.44 \\
\hline June & $\mathrm{n} / \mathrm{d}$ & 307 & 554 & 543 & 730 & 327 & 592 & 508.83 & 445.23 \\
\hline July & 169 & 182 & 226 & 362 & 363 & 205 & & 251.17 & 219.77 \\
\hline August & 207 & 159 & 182 & 328 & 226 & 193 & & 215.83 & 188.85 \\
\hline September & 1106 & 143 & 288 & 228 & 399 & 198 & & 393.67 & 344.46 \\
\hline October & 578 & 235 & 350 & 923 & 308 & 207 & & 433.50 & 379.31 \\
\hline November & 858 & 396 & 477 & 1300 & 701 & 203 & & 655.83 & 573.85 \\
\hline December & 695 & 485 & 680 & 873 & 421 & 442 & & 599.33 & 524.41 \\
\hline Year Average & & & & & & & & 615.81 & 538.83 \\
\hline $\begin{array}{l}\text { Averages for } \\
\text { the days of } \\
\text { measurements }\end{array}$ & & & & & & & & 470.51 & 559.01 \\
\hline
\end{tabular}

- At the Aiviekste estuary the only significant flow contribution is made to the river Daugava, which increases the flow rate in both the explored spans and between them. Thus we can assume that the data in the $1^{\text {st }}$ span column of Table 1 represent the flow rates in the whole "FIRST part" of the river [4].

- Approximate flow rate data for the "SECOND part" of the river (before the Aiviekste estuary) can be obtained by reducing the figures in the $1^{\text {st }}$ span column of Table 1 proportionally to the mentioned Aiviekste contribution. According to [6] and the data obtained in our measurements and calculations, the Aiviekste waters increase Daugava's flow rate 
by $\sim 1 / 8$. Therefore, the flow rate in the $2^{\text {nd }}$ span of the river can be obtained by reducing the figures of flow rate in the $1^{\text {st }}$ span by $1 / 8$. Thus calculated data are shown in the $2^{\text {nd }}$ span column of Table 1 .

- Comparison of the statistical data in Table 1 with the calculated flow rates for the days of measurements (the last three rows in Table 1) shows that these latter differ only insignificantly from the statistical observation data. Thus, the measurement data comply with the real situation and can be used to estimate the potential of the explored river spans for electricity production at HKPPs. Differences between the flow rates at the same places can be explained by rainfalls as the greatest flow rate values were obtained in rainy days.

3. On the market, hydrokinetic devices are offered which allow industrial production of electricity from the flows of very different depths (starting from as low as $1.5 \mathrm{~m}$ ). Thus, in general all the explored segments of the river (being not contradictory to any relevant technological solution) are suitable for electricity production at an HKPP.

The currently offered devices of the type are capable of producing electricity at the flow velocities starting from $0.5-0.6 \mathrm{~m} / \mathrm{s}$ (depending on the model of the device and the relevant technology [1]).

Thus, some of the explored river spans/segments can be used for electricity production right now, and all of them are expected to be usable in the foreseeable future with advances in the hydrokinetic technologies. The data on all explored spans/segments of the river could be used for further analysis.

\section{DISCUSSION}

Results of measurements taken on the adjacent cross-sections at different times and flow rates and the relevant calculation data allow the following to be stated:

- the water level increases with flow rate;

- this causes changes in the flow cross-sectional area;

- these changes mean that the velocity of the flow at its different rates varies insignificantly and specifically for each particular location;

- taking into account that hydrokinetic devices will be used only in the river cross-sections where water is flowing throughout the year, the seasonal flow fluctuations may be ignored.

All this can be confirmed by corresponding data for cross-sections that are located in the same or adjacent places but measured at different times and flow rates (see Table 2).

The adjacent cross-sections in Table 2 are: 10, 11; 12, 13, 14; 20, 21, 22; and 24, 25 (for geographical location of some cross-sections see Fig. 1).

As follows from Table 2, the flow rate variations can cause decrease as well as increase in the flow velocity (e.g., an increase in the flow rate can lead to a decrease in the flow velocity). It is also obvious that the flow velocity variations are proportionally smaller than those in the flow rates. Therefore, these former exert only insignificant influence on the amount of electrical energy to be produced 
by a hydrokinetic power plant sited in the place of river with water flowing all year long. This is due to the fact that the flow rate variations mainly cause those in the water level of a river and, therefore, also in its cross-sectional area while not changing significantly the flow velocity. This once more evidences that the HKPP is a stable and predictable source of energy, both in a long- and especially in a short-term. The main inference is therefore that the river flow velocity in particular places remains practically invariable at any time of the year.

Table 2

Flow rate - flow velocity ratios in different cross-sections of the river Daugava

\begin{tabular}{|c|c|c|c|c|c|c|c|c|c|c|}
\hline $\begin{array}{l}\text { Cross- } \\
\text { section } \\
\#\end{array}$ & 10 & 11 & 12 & 13 & 14 & 20 & 21 & 22 & 24 & 25 \\
\hline $\begin{array}{c}\text { Flow } \\
\text { rate } \\
\left(\mathrm{m}^{3} / \mathrm{s}\right)\end{array}$ & 811.04 & 936.19 & 809.54 & 885.35 & 1031.93 & 710.73 & 649.40 & 652.52 & 359.15 & 480.86 \\
\hline $\begin{array}{l}\text { Change } \\
\text { in flow } \\
\text { rate \% }\end{array}$ & 13.37 & & 8.56 & 14.20 & & -9.44 & 0.49 & & 25.31 & \\
\hline $\begin{array}{c}\text { Flow } \\
\text { velocity } \\
(\mathrm{m} / \mathrm{s})\end{array}$ & 0.43 & 0.42 & 0.43 & 0.40 & 0.41 & 0.38 & 0.42 & 0.44 & 0.52 & 0.52 \\
\hline $\begin{array}{c}\text { Change } \\
\text { in flow } \\
\text { velocity } \\
\%\end{array}$ & -1.58 & & -8.63 & 3.87 & & 10.03 & 4.77 & & 0.30 & \\
\hline
\end{tabular}

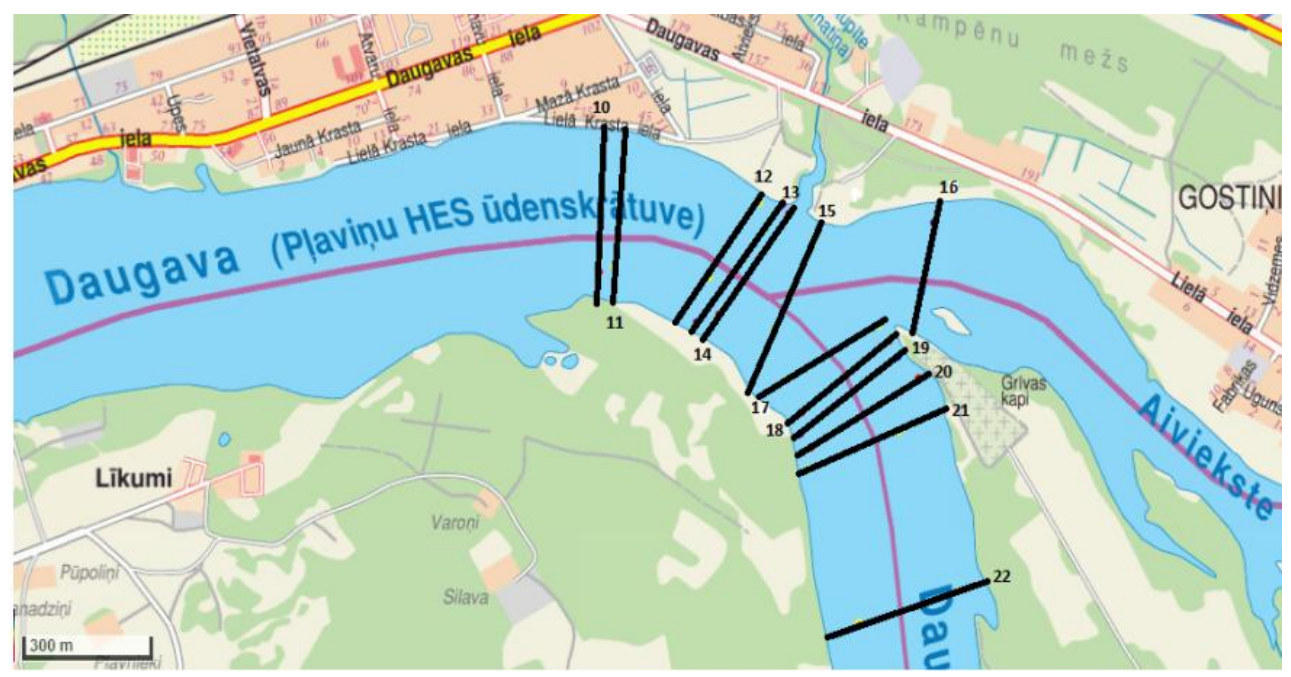

Fig. 1. Geographical location of the analyzed cross-sections of the river Daugava.

\section{CONCLUSIONS}

Analysis of the results obtained in the work allows the following conclusions to be drawn:

- The proposed methods can be used in the energy potential estimation for any river or its span where it is possible to sail using a boat or any similar floating means that can be kept immovable against the riverbanks. 
- Statistical data on the river flow rates (provided by observation stations or received otherwise) are highly valuable for validation of the results obtained from in-river measurements of the flow velocity, river bed depth, etc.

- Analysis of the measurement results for the river Daugava shows that the influence of flow rate variations on the flow velocity is insignificant.

\title{
ACKNOWLEDGEMENT
}

This work has received a financial support of the European Regional Development Fund according to the agreement between LLC „Environment, Bioenergetics and Biotechnology Competence Centre" and "Investment and Development Agency of Latvia" as of April 11, 2011 regarding implementation of the project \# L-KC-11 -0005. Complete research results are available at www.vbbkc.lv.

\section{REFERENCES}

1. Kari Surnes (Jan., 2010). Small-Scale Water Current Turbines for River Applications. ZERO - Zero Emission Resource Organisation; www.zero.no

2. Khan, M.J., Bhuyan, G., Iqbal, M.T., \& Quaicoe, J.E. (2009). Hydrokinetic energy conversion systems and assessment of horizontal and vertical axis turbines for river and tidal applications: A technology status review. Applied Energy, 95 (6), 35-51.

3. Khan M.J., Iqbal, M.T., \& Quaicoe, J.E. (2008). River current energy conversion systems: progress, prospects and challenges. Renewable and Sustainable Energy Reviews, 12(8), 2177-2193.

4. Kalnacs, A., Kalnacs, J., Mutule, \& A., Pērsis, U. (2013). Potential of the lower Daugava for siting hydrokinetic turbines. Latv. J. Phys. Tech. Sci., 50 (2), 3-14.

5. Manual on Stream Gauging (2010). Vol. 1, Ch. 6, Fieldwork WMO, No. 1004.

6. Internet site of the State Ltd. Liability Company "Latvian Environment, Geology and Meteorology Centre": www.meteo.lv (2011).

\section{METODIKA UPES ENERĢĒTISKĀ POTENCIĀLA NOVĒRTĒŠANAI AR HIDROKINĒTISKAJĀM IEKĀRTĀM STRĀDĀJOŠU ELEKTROSTACIJU IZVEIDOŠANAI.}

\author{
A. Kalnačs, J. Kalnačs, A. Mutule, U. Pērsis
}

Kopsavilkums

Rakstā ir aprakstîta metodika upes posmu potenciāla novērtēšanai elektroenerǵijas ražošanai ar hidrokinētiskajām iekārtām. Metodiku var izmantot jebkuras upes vai upes posma vērtēšanai, kurā iespējams pārvietoties ar laivu vai citu peldlīdzekli un noturēt šo peldlīdzekli nekustīgu attiecībā pret upes krastiem. Metodika atvieglo un samazina izmaksas turpmākiem pētījumiem.

Straumju ātruma mērījumu datu validācijai un papildus informācijai upju (posmu) novērtēšanai, ļoti noderīgi ir upju novērojumu staciju statistiskie dati par upju caurteces apjomiem. To izmantošana ir iekḷauta metodikā un tās lietošanas piemērā. 
Balstoties uz Daugavā veikto mērījumu analīzi, ir secināts, ka caurplūdes izmainas maz ietekmē straumes ātrumu konkrētajā vietā. Tas apliecina, ka hidrokinētiskās iekārtas ir stabils un viegli prognozējams elektroenerǵijas avots gan ilgtermiņā, gan, jo sevišķi, īstermiņāa.

21.01.2014. 